\title{
Wearing Surgical Masks Coupled With Restricting the Flow of People in Patient Wards Versus Preventive Atomization Inhalation in Preventing Fever After General Anesthesia Surgery: A Retrospective Analysis During COVID-19
}

\section{Tingli Chen}

Southern Medical University Nanfang Hospital https://orcid.org/0000-0003-4126-3539

\section{Lina Hou}

Southern Medical University Nanfang Hospital

Kai Sun

Southern Medical University Nanfang Hospital

Qiang Wei

Southern Medical University Nanfang Hospital

Fei Li

Southern Medical University Nanfang Hospital

Wanlong Tan ( $\sim$ twl42087@163.com)

Department of Urology, Nanfang Hospital, Southern Medical University, Guangzhou, Guangdong 510515, P.R.China

\section{Research}

Keywords: Fever, General anesthesia surgery, Atomization inhalation, Wearing surgical masks, Corona Virus Disease 2019 (COVID-19)

Posted Date: October 12th, 2020

DOI: https://doi.org/10.21203/rs.3.rs-89205/v1

License: (ㅇ (i) This work is licensed under a Creative Commons Attribution 4.0 International License. Read Full License 


\section{Abstract}

Background: The COVID-19 could be transmitted through aerosols, and aerosol can be produced by atomization inhalation. Preventative aerosol inhalation is prohibited in our hospital during COVID-19, however the number of cases of fever after surgery has not increased significantly. We want to know whether wearing surgical masks coupled with restricting the flow of people in patient wards has same effect with preventive atomization inhalation in preventing fever after surgery, and we wonder whether preventive atomization inhalation is unnecessary during COVID-19, as long as strictly wearing surgical masks and restricting the flow of people in patient wards have been met.

Methods: Eight kinds of common surgery were covered in this retrospective analysis, including total thyroidectomy (for the treatment of thyroid carcinoma), total adrenalectomy (adrenal tumor), radical gastrectomy (gastric cancer), radical nephrectomy (renal cell carcinoma), radical prostatectomy (prostate cancer), radical resection for sigmoid colon cancer, radical resection for rectal cancer and appendectomy (appendicitis). Cases in Group A underwent preventive atomization inhalation whilst cases in group B wore surgical masks and restricted the flow of people in patient wards. Occurrence of fever, occurrence of fever recurrence and the maximum temperature in the first week after surgery were analyzed in this study.

Results: No significant differences can be seen between group A and group B in terms of occurrence of fever, occurrence of fever recurrence and the maximum temperature after surgery in the first week.

Conclusion: Wearing surgical masks combined with restricting the flow of people in patient wards has same effect with preventive atomization inhalation in preventing fever after general anesthesia surgery, which means, during COVID-19, preventive atomization inhalation might not be necessary as long as strictly wearing surgical masks and restricting the flow of people in patient wards have been met.

\section{Background}

At the end of 2019, novel coronavirus pneumonia (NCP) broke out in Wuhan and swept the rest of China and many other countries around the world. NCP was officially named as Corona virus Disease 2019 (COVID-19) by World Health Organization (WHO) (1). COVID-19 is caused by 'severe acute respiratory syndrome coronavirus 2' (SARS-CoV-2), which is closely related to 'severe acute respiratory syndrome' (SARS) and 'Middle Eastern respiratory syndrome' (MERS) (2). The clinical characteristics of COVID-19 are varied, ranging from having no symptoms to having a slight fever, mild cough, and dyspnea to respiratory failure and even death $(3,4)$. Person-to-person transmission of COVID-19 was declared by WHO on March $11,2020(5,6)$.

SARS-CoV-2 was founded in the air of wards that contained COVID-19 patients $(7,8)$. The COVID-19 could also be transmitted through aerosols (9). Aerosol can be produced by atomization inhalation (10). Various measures were taken to stop virus transmissions for patients in wards at the Nanfang Hospital of Southern Medical University during the COVID-19 period (according to Guide for the Prevention and 
Treatment of Coronavirus Disease 2019), including wearing surgical masks, social distancing, isolation, stopping preventative aerosol inhalation and restricting the flow of people in patient wards (11).

General anesthesia surgery is common and is usually performed under endotracheal intubation. Mucosa lining the respiratory tract can be easily damaged after endotracheal intubation, which would increase the possibility of pathogen invasion and cause a respiratory tract infection (12). Atomization inhalation has the ability to protect the respiratory mucosa and dilute sputum, which is often used to prevent fever after general anesthesia surgery (13-16). Stopping preventative aerosol inhalation made both patients and doctors worried with the possibility that an increase of fever could occur. Interestingly, the surgical patients, which were wearing surgical masks and having the flow of people in their wards restricted, had same chance of getting fever with the patients undergoing preventive atomization inhalation in our retrospective analysis. Our findings indicated that preventive aerosol inhalation might not be necessary as long as the conditions of strictly wearing surgical masks combined with restricting the flow of people in patient wards during COVID-19 have been met.

\section{Methods}

\section{Patients}

Studies were conducted with the approval from the bioethics committee of Nanfang hospital, Southern medical university (Guangzhou, China). The surgical patients in our study were from Nanfang Hospital of Southern Medical University. Eight kinds of common surgery were covered in this retrospective analysis, including total thyroidectomy, total adrenalectomy, radical gastrectomy, radical nephrectomy, radical prostatectomy, radical resection for sigmoid colon cancer, radical resection for rectal cancer and appendectomy. All the procedures were performed under general anesthesia and tracheal intubation.

The criteria for patients consisted of: 1) patient had no fever before surgery (body temperature $<37.3^{\circ} \mathrm{C}$ in the absence of antipyretic), 2) patient had no basic respiratory diseases, no cough or sputum, no smoking history, 3) patient hadn't had surgery in the past year, 4) patient had no hypertension and diabetes and 5) there was no postoperative incision infection.

Surgical cases from February 2019 to August 2019 were collected to make up group A, in which group preventive atomization inhalation was performed on every patient after surgery, but the wearing of surgical masks and flow-control in patient wards were not conducted. While on the contrary, cases during COVID-19 were collected from February 2020 to August 2020 in order to make up group B. All of patients in group B wore surgical masks and had the flow of people in their wards greatly restricted, however they did not have preventive atomization inhalation performed.

\section{Preventive atomization inhalation}

The preventive atomization inhalation procedure was performed in our hospital as following: $2 \mathrm{mg}$ of Budesonide suspension (Primicomesu) and $5 \mathrm{mg}$ of Terbutaline atomizer (Boliconix) were dissolved in 
$5 \mathrm{ml}$ physiological saline, which were then inhaled with oxygen (oxygen flow $2 \mathrm{~L} / \mathrm{min}$ ) at room temperature $\left(18-24^{\circ} \mathrm{C}\right)$, twice a day for 20 minutes each.

\section{Wearing surgical masks}

Everyone in the hospital must wear surgical masks during the COVID-19, including all patients, their caretakers and medical workers. The mouth and nose must be covered completely to ensure that no airleaking occurs when wearing the surgical mask. The outside surface of surgical masks cannot be touched, and each surgical mask must be replaced regularly in every 4-6 hours. All the used masks are treated as medical waste (11).

\section{Restricting the flow of people in patient wards}

The measures taken in order to restrict the flow of people in our hospital's patient wards during the COVID19 included: 1) Nucleic acid tests for COVID-19 must be negative for everyone in patient wards. 2) To avoid the replacement of caretakers halfway through, each patient and their respective caretaker wore special wristbands which could not be reused or removed. 3) All patients and their respective caretakers could not leave the hospital or patient wards without permission. 4) Visits were prohibited in the patient wards (11).

\section{Body temperature}

The patient's body temperature was measured twice a day before surgery, increased to four times a day after surgery, until the patient discharged from hospital. The infrared thermometer was used routinely, taking two measurements every time to produce an average. If the difference between the two measurements was greater than $0.2^{\circ} \mathrm{C}$, a traditional mercury thermometer was to instead be used.

Fever after surgery is defined as any recorded body temperature $\geq 38^{\circ} \mathrm{C}$ in the first week after surgery. Fever recurrence is defined as body temperature $\geq 38^{\circ} \mathrm{C}$ again after falling below $37.3^{\circ} \mathrm{C}$ in the first week after surgery, which means that the patient has multiple fever and the case is complicated. In our study, occurrence of fever is defined as the proportion of patients with fever after surgery in all patients, and occurrence of fever recurrence is defined as the proportion of patients with fever recurrence in all patients. Occurrence of fever, occurrence of fever recurrence and the maximum temperature in the first week after surgery were analyzed in this study. $(17,18)$

\section{Statistical analysis}

Continuous values were expressed as the mean \pm standard deviation (SD), and categorical data was presented by a number followed by percentage (\%). All the data was collected and statistically analyzed by SPSS software 22.0 (SPSS, Chicago, IL, USA). Pearson's chi-square test, Fisher's exact test, independentsamples t-test would be used whenever appropriate. $P$-value $<0.05$ was considered to be statistically significant.

\section{Result}


Table 1 has shown the characteristics of patients in our study population. For each particular type of surgery, there were no significant differences between group A and group B in terms of their age, gender, body mass index (BMI), operation time (OT), intraoperative bleeding volume (IBV) nor the use of antibiotics. 
Table 1

Characteristics of the included surgical patients

\begin{tabular}{|c|c|c|c|c|c|c|c|}
\hline Surgery & & $\begin{array}{l}\text { Age } \\
\text { (years) }\end{array}$ & Gender(male\%) & BMI & OT(min) & IBV(ml) & Antibiotics \\
\hline \multirow[t]{3}{*}{$\begin{array}{l}\text { Total } \\
\text { thyroidectomy }\end{array}$} & $\begin{array}{l}\text { Group } \\
\text { A }\end{array}$ & $\begin{array}{l}42.54 \\
\pm 4.23\end{array}$ & $54.9 \%$ & $\begin{array}{l}22.37 \\
\pm 3.13\end{array}$ & $\begin{array}{l}55.34 \pm \\
6.23\end{array}$ & $\begin{array}{l}8.23 \pm \\
2.31\end{array}$ & $\begin{array}{l}\text { No } \\
\text { antibiotics }\end{array}$ \\
\hline & $\begin{array}{l}\text { Group } \\
\text { B }\end{array}$ & $\begin{array}{l}44.12 \\
\pm 2.97\end{array}$ & $52.3 \%$ & $\begin{array}{l}23.24 \\
\pm 2.93\end{array}$ & $\begin{array}{l}52.79 \pm \\
5.30\end{array}$ & $\begin{array}{l}6.99 \pm \\
3.27\end{array}$ & $\begin{array}{l}\text { No } \\
\text { antibiotics }\end{array}$ \\
\hline & $\begin{array}{l}P \text { - } \\
\text { value }\end{array}$ & 0.550 & 0.244 & 0.643 & 0.734 & 0.357 & - \\
\hline \multirow{3}{*}{$\begin{array}{l}\text { Total } \\
\text { adrenalectomy }\end{array}$} & $\begin{array}{l}\text { Group } \\
\text { A }\end{array}$ & $\begin{array}{l}54.62 \\
\pm 3.21\end{array}$ & $43.9 \%$ & $\begin{array}{l}24.17 \\
\pm 2.13\end{array}$ & $\begin{array}{l}73.34 \pm \\
5.61\end{array}$ & $\begin{array}{l}13.22 \\
\pm 3.47\end{array}$ & $\begin{array}{l}\text { No } \\
\text { antibiotics }\end{array}$ \\
\hline & $\begin{array}{l}\text { Group } \\
\text { B }\end{array}$ & $\begin{array}{l}57.10 \\
\pm 2.37\end{array}$ & $42.3 \%$ & $\begin{array}{l}25.24 \\
\pm 1.93\end{array}$ & $\begin{array}{l}64.79 \pm \\
4.30\end{array}$ & $\begin{array}{l}12.92 \\
\pm 3.51\end{array}$ & $\begin{array}{l}\text { No } \\
\text { antibiotics }\end{array}$ \\
\hline & $\begin{array}{l}P \text { - } \\
\text { value }\end{array}$ & 0.640 & 0.470 & 0.563 & 0.524 & 0.637 & - \\
\hline \multirow[t]{3}{*}{$\begin{array}{l}\text { Radical } \\
\text { gastrectomy }\end{array}$} & $\begin{array}{l}\text { Group } \\
\text { A }\end{array}$ & $\begin{array}{l}61.33 \\
\pm 7.94\end{array}$ & $59.1 \%$ & $\begin{array}{l}23.95 \\
\pm 2.53\end{array}$ & $\begin{array}{l}197.22 \\
\pm 16.31\end{array}$ & $\begin{array}{l}64.19 \\
\pm 5.41\end{array}$ & Moxalactam* \\
\hline & $\begin{array}{l}\text { Group } \\
\text { B }\end{array}$ & $\begin{array}{l}59.10 \\
\pm 6.35\end{array}$ & $57.6 \%$ & $\begin{array}{l}24.16 \\
\pm 3.03\end{array}$ & $\begin{array}{l}205.79 \\
\pm 17.28\end{array}$ & $\begin{array}{l}69.33 \\
\pm 3.79\end{array}$ & Moxalactam* \\
\hline & $\begin{array}{l}P \text { - } \\
\text { value }\end{array}$ & 0.593 & 0.496 & 0.293 & 0.627 & 0.532 & - \\
\hline \multirow[t]{3}{*}{$\begin{array}{l}\text { Radical } \\
\text { nephrectomy }\end{array}$} & $\begin{array}{l}\text { Group } \\
\text { A }\end{array}$ & $\begin{array}{l}57.31 \\
\pm 6.74\end{array}$ & $55.1 \%$ & $\begin{array}{l}25.52 \\
\pm 2.13\end{array}$ & $\begin{array}{l}117.54 \\
\pm 9.35\end{array}$ & $\begin{array}{l}23.59 \\
\pm 4.43\end{array}$ & Moxalactam* \\
\hline & $\begin{array}{l}\text { Group } \\
\text { B }\end{array}$ & $\begin{array}{l}58.10 \\
\pm 5.35\end{array}$ & $53.0 \%$ & $\begin{array}{l}24.97 \\
\pm 3.14\end{array}$ & $\begin{array}{l}107.69 \\
\pm 7.31\end{array}$ & $\begin{array}{l}26.31 \\
\pm 3.37\end{array}$ & Moxalactam* \\
\hline & $\begin{array}{l}P \text { - } \\
\text { value }\end{array}$ & 0.613 & 0.346 & 0.287 & 0.460 & 0.392 & - \\
\hline \multirow[t]{3}{*}{$\begin{array}{l}\text { Radical } \\
\text { prostatectomy }\end{array}$} & $\begin{array}{l}\text { Group } \\
\text { A }\end{array}$ & $\begin{array}{l}71.23 \\
\pm 8.94\end{array}$ & $100.0 \%$ & $\begin{array}{l}21.95 \\
\pm 2.37\end{array}$ & $\begin{array}{l}227.16 \\
\pm 21.31\end{array}$ & $\begin{array}{l}85.19 \\
\pm 10.41\end{array}$ & Moxalactam* \\
\hline & $\begin{array}{l}\text { Group } \\
\text { B }\end{array}$ & $\begin{array}{l}69.10 \\
\pm 8.36\end{array}$ & $100.0 \%$ & $\begin{array}{l}21.84 \\
\pm 3.03\end{array}$ & $\begin{array}{l}213.55 \\
\pm 23.61\end{array}$ & $\begin{array}{l}77.31 \\
\pm 12.79\end{array}$ & Moxalactam* \\
\hline & $\begin{array}{l}P \text { - } \\
\text { value }\end{array}$ & 0.671 & 1.000 & 0.472 & 0.513 & 0.481 & - \\
\hline \multicolumn{8}{|c|}{$\begin{array}{l}\text { * Moxalactam was used as following: } 1 \mathrm{~g} \text { of Moxalactam was dissolved in } 100 \mathrm{ml} \text { physiological saline, } \\
\text { by intravenous drip, twice a day for three days. }\end{array}$} \\
\hline \multicolumn{8}{|c|}{ BMI: body mass index } \\
\hline \multicolumn{8}{|c|}{ OT: operation time } \\
\hline \multicolumn{8}{|c|}{ IBV: intraoperative bleeding volume } \\
\hline
\end{tabular}




\begin{tabular}{|c|c|c|c|c|c|c|c|}
\hline Surgery & & $\begin{array}{l}\text { Age } \\
\text { (years) }\end{array}$ & Gender(male\%) & BMI & OT(min) & IBV(ml) & Antibiotics \\
\hline \multirow{3}{*}{$\begin{array}{l}\text { Radical } \\
\text { resection for } \\
\text { sigmoid colon } \\
\text { cancer }\end{array}$} & $\begin{array}{l}\text { Group } \\
\text { A }\end{array}$ & $\begin{array}{l}57.31 \\
\pm 6.34\end{array}$ & $59.6 \%$ & $\begin{array}{l}24.95 \\
\pm 4.53\end{array}$ & $\begin{array}{l}153.12 \\
\pm 13.26\end{array}$ & $\begin{array}{l}42.19 \\
\pm 7.41\end{array}$ & Moxalactam* \\
\hline & $\begin{array}{l}\text { Group } \\
\text { B }\end{array}$ & $\begin{array}{l}59.60 \\
\pm 4.35\end{array}$ & $57.6 \%$ & $\begin{array}{l}25.16 \\
\pm 3.17\end{array}$ & $\begin{array}{l}147.79 \\
\pm 11.68\end{array}$ & $\begin{array}{l}47.33 \\
\pm 5.79\end{array}$ & Moxalactam* \\
\hline & $\begin{array}{l}P \text { - } \\
\text { value }\end{array}$ & 0.437 & 0.318 & 0.343 & 0.479 & 0.392 & - \\
\hline \multirow{3}{*}{$\begin{array}{l}\text { Radical } \\
\text { resection for } \\
\text { rectal cancer }\end{array}$} & $\begin{array}{l}\text { Group } \\
\text { A }\end{array}$ & $\begin{array}{l}65.23 \\
\pm 5.14\end{array}$ & $62.1 \%$ & $\begin{array}{l}26.35 \\
\pm 3.37\end{array}$ & $\begin{array}{l}159.16 \\
\pm 11.57\end{array}$ & $\begin{array}{l}63.19 \\
\pm 8.41\end{array}$ & Moxalactam* \\
\hline & $\begin{array}{l}\text { Group } \\
\text { B }\end{array}$ & $\begin{array}{l}67.10 \\
\pm 4.36\end{array}$ & $59.6 \%$ & $\begin{array}{l}25.84 \\
\pm 2.97\end{array}$ & $\begin{array}{l}162.25 \\
\pm 9.61\end{array}$ & $\begin{array}{l}61.94 \\
\pm 9.79\end{array}$ & Moxalactam* \\
\hline & $\begin{array}{l}P \text { - } \\
\text { value }\end{array}$ & 0.691 & 0.252 & 0.392 & 0.483 & 0.562 & - \\
\hline \multirow[t]{3}{*}{ Appendectomy } & $\begin{array}{l}\text { Group } \\
\text { A }\end{array}$ & $\begin{array}{l}25.23 \\
\pm 6.14\end{array}$ & $50.9 \%$ & $\begin{array}{l}22.17 \\
\pm 2.67\end{array}$ & $\begin{array}{l}44.16 \pm \\
6.57\end{array}$ & $\begin{array}{l}8.59 \pm \\
2.41\end{array}$ & Moxalactam* \\
\hline & $\begin{array}{l}\text { Group } \\
\text { B }\end{array}$ & $\begin{array}{l}27.10 \\
\pm 5.36\end{array}$ & $52.4 \%$ & $\begin{array}{l}21.99 \\
\pm 3.07\end{array}$ & $\begin{array}{l}46.15 \pm \\
5.61\end{array}$ & $\begin{array}{l}9.34 \pm \\
3.09\end{array}$ & Moxalactam* \\
\hline & $\begin{array}{l}P- \\
\text { value }\end{array}$ & 0.371 & 0.502 & 0.573 & 0.487 & 0.704 & - \\
\hline \multicolumn{8}{|c|}{$\begin{array}{l}\text { * Moxalactam was used as following: } 1 \mathrm{~g} \text { of Moxalactam was dissolved in } 100 \mathrm{ml} \text { physiological saline, } \\
\text { by intravenous drip, twice a day for three days. }\end{array}$} \\
\hline \multicolumn{8}{|c|}{ BMI: body mass index } \\
\hline \multicolumn{8}{|c|}{ OT: operation time } \\
\hline \multicolumn{8}{|c|}{ IBV: intraoperative bleeding volume } \\
\hline
\end{tabular}

As for occurrence of fever, there were no significant differences between group $A$ and group $B$ in terms of total thyroidectomy $(P=0.113)$, total adrenalectomy $(P=0.360)$, radical gastrectomy $(P=0.060)$, radical nephrectomy $(P=0.685)$, radical prostatectomy $(P=0.451)$, radical resection for sigmoid colon cancer $(P=$ $0.248)$, radical resection for rectal $\operatorname{cancer}(P=0.071)$ and appendectomy $(P=0.459)$. (Table 2$)$ 
Table 2

Occurrence of fever

\begin{tabular}{|llll|}
\hline Surgery & Group A & Group B & $P$-value \\
\hline Total thyroidectomy & $5 / 55(9.1 \%)$ & $1 / 56(1.8 \%)$ & 0.113 \\
\hline Total adrenalectomy & $4 / 43(9.3 \%)$ & $1 / 41(2.4 \%)$ & 0.360 \\
\hline Radical gastrectomy & $9 / 50(18.0 \%)$ & $3 / 51(5.9 \%)$ & 0.060 \\
\hline Radical nephrectomy & $4 / 33(12.1 \%)$ & $2 / 26(7.7 \%)$ & 0.685 \\
\hline Radical prostatectomy & $6 / 19(31.6 \%)$ & $3 / 17(17.6 \%)$ & 0.451 \\
\hline Radical resection for sigmoid colon cancer & $11 / 54(20.4 \%)$ & $7 / 57(12.3 \%)$ & 0.248 \\
\hline Radical resection for rectal cancer & $13 / 65(20.0 \%)$ & $6 / 67(9.0 \%)$ & 0.071 \\
\hline Appendectomy & $5 / 31(16.1 \%)$ & $3 / 35(8.6 \%)$ & 0.459 \\
\hline
\end{tabular}

Table 3 has shown that no fever recurrence happened in total thyroidectomy, total adrenalectomy and radical nephrectomy. As for occurrence of fever recurrence, there were no significant differences between group $A$ and group $B$ in terms of radical gastrectomy $(P=0.436)$, radical prostatectomy $(P=1.000)$, radical resection for sigmoid colon cancer $(P=0.674)$, radical resection for rectal cancer $(P=0.300)$ and appendectomy $(P=0.597)$.

Table 3

Occurrence of fever recurrence

\begin{tabular}{|llll|}
\hline Surgery & Group A & Group B & $P$-value \\
\hline Total thyroidectomy & $0 / 55(0 \%)$ & $0 / 56(0 \%)$ & - \\
\hline Total adrenalectomy & $0 / 43(0 \%)$ & $0 / 41(0 \%)$ & - \\
\hline Radical gastrectomy & $4 / 50(8.0 \%)$ & $2 / 51(3.9 \%)$ & 0.436 \\
\hline Radical nephrectomy & $0 / 33(0 \%)$ & $0 / 26(0 \%)$ & - \\
\hline Radical prostatectomy & $3 / 19(15.8 \%)$ & $2 / 17(11.8 \%)$ & 1.000 \\
\hline Radical resection for sigmoid colon cancer & $6 / 54(11.1 \%)$ & $4 / 57(7.0 \%)$ & 0.674 \\
\hline Radical resection for rectal cancer & $7 / 65(10.8 \%)$ & $3 / 67(4.5 \%)$ & 0.300 \\
\hline Appendectomy & $2 / 31(6.5 \%)$ & $1 / 35(2.9 \%)$ & 0.597 \\
\hline
\end{tabular}

As for the maximum temperature in the first week after surgery, there were no significant differences between group $A$ and group $B$ in terms of radical gastrectomy $\left(38.4 \pm 0.5 \mathrm{vs} .38 .3 \pm 0.4^{\circ} \mathrm{C}, \mathrm{P}=0.591\right)$, radical prostatectomy $\left(38.7 \pm 0.6 \mathrm{vs} .38 .6 \pm 0.8^{\circ} \mathrm{C}, \mathrm{P}=0.472\right)$, radical resection for sigmoid colon cancer $(38.3 \pm$ $\left.0.9 v s .38 .4 \pm 0.5^{\circ} \mathrm{C}, \mathrm{P}=0.568\right)$, radical resection for rectal cancer $\left(38.6 \pm 0.7 \mathrm{vs} .38 .4 \pm 0.6^{\circ} \mathrm{C}, \mathrm{P}=0.443\right)$ and appendectomy $\left(38.4 \pm 0.7 v s .38 .3 \pm 0.5^{\circ} \mathrm{C}, \mathrm{P}=0.376\right)$. (Table 4) 
Table 4

The maximum temperature in the first week after surgery $\left({ }^{\circ} \mathrm{C}\right)$

\begin{tabular}{|llll|}
\hline Surgery & Group A & Group B & $P$-value \\
\hline Radical gastrectomy & $38.4 \pm 0.5$ & $38.3 \pm 0.4$ & 0.591 \\
\hline Radical prostatectomy & $38.7 \pm 0.6$ & $38.6 \pm 0.8$ & 0.472 \\
\hline Radical resection for sigmoid colon cancer & $38.3 \pm 0.9$ & $38.4 \pm 0.5$ & 0.568 \\
\hline Radical resection for rectal cancer & $38.6 \pm 0.7$ & $38.4 \pm 0.6$ & 0.443 \\
\hline Appendectomy & $38.4 \pm 0.7$ & $38.3 \pm 0.5$ & 0.376 \\
\hline
\end{tabular}

\section{Discussion}

Fever is a common postoperative complication which is defined as any recorded body temperature $\geq$ $38^{\circ} \mathrm{C}$ in the first week after surgery (19). There are several methods to prevent postoperative fever including atomization inhalation, wearing surgical masks, restricting the flow of people in patient wards and so on. All the methods that are mentioned above work through reducing the possibility of respiratory tract infection.

Atomization inhalation is often used to relieve pharynx and larynx pain after tracheal intubation and to treat oral mucositis after radiotherapy for head and neck cancer (20). Atomization inhalation can be also used as a method of drug administration, for example, in treating bacterial infection, viral infection, asthma and chronic obstructive pulmonary disease (COPD) (21-23). Preventive atomization inhalation is considered to be an important method to prevent respiratory tract infection and fever, because it can keep the respiratory mucosa moist, promote the healing of damaged respiratory epithelial cells and diluting sputum. The common procedure of preventive atomization inhalation in our hospital involved the administration of Budesonide and Terbutaline. Budesonide is a common corticosteroid, which can inhibit respiratory inflammation, relieve bronchospasm and reduce airway hyperreactivity (AHR) (22). Terbutaline is a $\beta 2$-receptor agonist, which has high selectivity for bronchial smooth muscle to dilate the bronchi and reduce AHR (24).

Wearing surgical masks can prevent pathogenic microorganisms from entering the respiratory tract effectively which is often used to prevent respiratory tract infection and fever (25). Unfortunately, wearing surgical masks is often ignored by patients. People subconsciously believe that procedures involving the administration of drugs are more effective. Given that ward visits are necessary, restricting the flow of people in patient wards completely is tough to achieve. The outbreak of COVID-19 provided us with an opportunity to make the necessary comparisons, because wearing surgical masks and restricting the flow of people in patient wards was conducted strictly in our hospital during COVID-19.

The findings in our study showed that no significant differences can be seen between group A and group B in terms of occurrence of fever, occurrence of fever recurrence and the maximum temperature in the first week after surgery. Wearing surgical masks combined with restricting the flow of people in patient wards 
has same effect with preventive atomization inhalation in preventing fever after surgery, which is of great significance in guiding clinical work.

Several limitations of this current study need to be taken into account when considering its contributions. First, this retrospective study consisted of data from a single institution which could potentially have a selection bias. With regards to this, the large prospective cohort observational studies, including diverse populations are needed in the future. Second, we only covered eight different kinds of surgeries during our study. In order to make the study more credible, more types of surgeries should be included. Finally, although some important confound factors (age, gender, BMI, OT, IBV, the use of antibiotics, et al) have been adjusted in our analysis, we could not rule out the possibility that other unknown or unmeasured factors (psychological suggestion during COVID 19, et al) could affect the correlations.

To sum up, wearing surgical masks combined with restricting the flow of people in patient wards has same effect with preventive atomization inhalation in preventing fever after general anesthesia surgery, which means, during COVID-19, preventive atomization inhalation might not be necessary as long as strictly wearing surgical masks and restricting the flow of people in patient wards have been met.

\section{Abbreviations}

NCP

novel coronavirus pneumonia

COVID-19

Corona virus Disease 2019

WHO

World Health Organization

SARS-CoV-2

severe acute respiratory syndrome coronavirus 2

SARS

severe acute respiratory syndrome

MERS

Middle Eastern respiratory syndrome

$\mathrm{BMI}$

body mass index

OT

operation time

IBV

intraoperative bleeding volume

\section{Declarations}

Ethics approval and consent to participate 
Studies were conducted with the approval from the bioethics committee of Nanfang hospital, Southern medical university (Guangzhou, China), reference number: 2020BL-072-04.

\section{Consent for publication}

Not applicable.

\section{Availability of data and materials}

All data generated or analyzed during this study are included in this published article.

\section{Competing interests}

None.

\section{Funding}

No funding was received.

\section{Authors' contributions}

All authors have contributed significantly.

Tingli Chen: Project design, data Collection, data analysis, drafting and edited of the manuscript

Lina Hou: Data Collection and data analysis

Kai Sun: drafting of the manuscript

Qiang Wei: Data Collection

Fei Li: Project design and edited of the manuscript

Wanlong Tan: Project design and edited of the manuscript

\section{Acknowledgements}

Not applicable.

\section{References}

1. Li Q, Guan X, Wu P, Wang X, Zhou L, Tong Y, et al. Early Transmission Dynamics in Wuhan, China, of Novel Coronavirus-Infected Pneumonia. The New England journal of medicine. 2020;382(13):1199207.

2. de Wit E, van Doremalen N, Falzarano D, Munster VJ. SARS and MERS: recent insights into emerging coronaviruses. Nature reviews Microbiology. 2016;14(8):523-34. 
3. Ge H, Wang X, Yuan X, Xiao G, Wang C, Deng T, et al. The epidemiology and clinical information about COVID-19. European journal of clinical microbiology \& infectious diseases : official publication of the European Society of Clinical Microbiology. 2020;39(6):1011-9.

4. Jin YH, Cai L, Cheng ZS, Cheng H, Deng T, Fan YP, et al. A rapid advice guideline for the diagnosis and treatment of 2019 novel coronavirus (2019-nCoV) infected pneumonia (standard version). Military Medical Research. 2020;7(1):4.

5. Zhu N, Zhang D, Wang W, Li X, Yang B, Song J, et al. A Novel Coronavirus from Patients with Pneumonia in China, 2019. The New England journal of medicine. 2020;382(8):727-33.

6. Chan JF, Yuan S, Kok KH, To KK, Chu H, Yang J, et al. A familial cluster of pneumonia associated with the 2019 novel coronavirus indicating person-to-person transmission: a study of a family cluster. Lancet (London, England). 2020;395(10223):514-23.

7. Ong SWX, Tan YK, Chia PY, Lee TH, Ng OT, Wong MSY, et al. Air, Surface Environmental, and Personal Protective Equipment Contamination by Severe Acute Respiratory Syndrome Coronavirus 2 (SARSCoV-2) From a Symptomatic Patient. Jama. 2020;323(16):1610-2.

8. Guo ZD, Wang ZY, Zhang SF, Li X, Li L, Li C, et al. Aerosol and Surface Distribution of Severe Acute Respiratory Syndrome Coronavirus 2 in Hospital Wards, Wuhan, China, 2020. Emerging infectious diseases. 2020;26(7):1583-91.

9. Yu YX, Sun L, Yao K, Lou XT, Liang X, Zhao BW, et al. [Consideration and prevention for the aerosol transmission of 2019 novel coronavirus]. [Zhonghua yan ke za zhi] Chinese journal of ophthalmology. 2020;56(0):E008.

10. Johnson GR, Morawska L. The mechanism of breath aerosol formation. Journal of aerosol medicine and pulmonary drug delivery. 2009;22(3):229-37.

11. [Guide for the prevention and treatment of coronavirus disease 2019]. Zhonghua jie he he hu xi za zhi = Zhonghua jiehe he huxi zazhi = Chinese journal of tuberculosis and respiratory diseases. 2020;43(6):473-89.

12. Pacheco-Lopez PC, Berkow LC, Hillel AT, Akst LM. Complications of airway management. Respiratory care. 2014;59(6):1006-19; discussion 19-21.

13. Carvalho TC, McConville JT. The function and performance of aqueous aerosol devices for inhalation therapy. The Journal of pharmacy and pharmacology. 2016;68(5):556-78.

14. Li G, Wang JS, Qin SD, Zhang J, Du N, Zhang J, et al. [Clinical study of the oxygen drive aerosol inhalation with budesonide and ambroxol in the prevention of adult post-thoracotomy pneumonia]. Beijing da xue xue bao Yi xue ban = Journal of Peking University Health sciences. 2018;50(5):840-4.

15. Başdemir D, Nuhoğlu Y, Bahçeciler NN, Tükenmez F, Kotiloğlu E, Barlan IB, et al. Acute effect of inhaled budesonide on bronchial inflammation in asthmatic rats. The Journal of asthma : official journal of the Association for the Care of Asthma. 2001;38(6):461-7.

16. Tang HP, Li JC. [Atomization inhalation of ambroxol as an auxiliary therapy for severe pneumonia in neonates]. Zhongguo dang dai er ke za zhi = Chinese journal of contemporary pediatrics. 2006;8(3):249-50. 
17. Yousef MAA, Rosenfeld S. Evaluation of postoperative fever after surgical correction of neuromuscular scoliosis: implication on management. European spine journal : official publication of the European Spine Society, the European Spinal Deformity Society, and the European Section of the Cervical Spine Research Society. 2018;27(8):1690-7.

18. Maday KR, Hurt JB, Harrelson P, Porterfield J. Evaluating postoperative fever. JAAPA : official journal of the American Academy of Physician Assistants. 2016;29(10):23-8.

19. Bourget-Murray J, Heard BJ, Bansal R, Johnson AS, Powell J. Postoperative fever in the time of COVID19. Canadian journal of surgery Journal canadien de chirurgie. 2020;63(3):E231-e2.

20. Bai XH, Chen ZM, Ma LH, He Z, Li G. Prevention effect of low-temperature atomization inhalation for radiation induced oral mucositis in patients with head and neck cancer undergoing radiotherapy. Cancer management and research. 2019;11:4327-33.

21. Li Z, Fu XY, Fang XB, Li J, Chen T, Qiu LM, et al. [Clinical efficacy observation of atomization inhalation combined with oral administration of oseltamivir in 4 cases with $\mathrm{H} 7 \mathrm{~N} 9$ avian influenza]. Zhonghua yi xue za zhi. 2017;97(24):1883-7.

22. Kang Q, Zhang X, Liu S, Huang F. Correlation between the vitamin D levels and asthma attacks in children: Evaluation of the effects of combination therapy of atomization inhalation of budesonide, albuterol and vitamin D supplementation on asthmatic patients. Experimental and therapeutic medicine. 2018;15(1):727-32.

23. Jiang DH, Wang X, Liu LS, Ji DD, Zhang N. The effect of ventilator mask atomization inhalation of ipratropium bromide and budesonide suspension liquid in the treatment of COPD in acute exacerbation period on circulating levels of inflammation and prognosis. European review for medical and pharmacological sciences. 2017;21(22):5211-6.

24. Jacobson GA, Hostrup M. Terbutaline: level the playing field for inhaled $\beta(2)$-agonists by introducing a dosing and urine threshold. British journal of sports medicine. 2017;51(18):1323-4.

25. Maclntyre CR, Chughtai AA, Rahman B, Peng Y, Zhang Y, Seale H, et al. The efficacy of medical masks and respirators against respiratory infection in healthcare workers. Influenza and other respiratory viruses. 2017;11(6):511-7. 